\title{
Vasseuromys rambliensis sp. nov. (Gliridae, Mammalia) from the Ramblian (Lower Miocene) of the Tudela Formation (Ebro basin, Spain)
}

\author{
Francisco J. Ruiz-Sánchez, Xabier Murelaga, Matthijs Freudenthal, \\ Juan C. Larrasoaña and Miguel Garcés
}

\begin{abstract}
In this paper, a new species of Vasseuromys, $V$. rambliensis sp. nov., from the locality Pico del Fraile 1 (PF1, Ebro basin, North-eastern Spain) is described. The association of Ligerimys, Peridyromys murinus and Simplomys simplicidens, and the absence of Eucricetodon and Democricetodon, allows dating of the PF1 locality as Late Ramblian (Early Miocene, MN3, local zone A). Main diagnostic features of $V$. rambliensis sp. nov. are the presence of four extra ridges in the lower molars, a very reduced anterotropid and a metaloph connected to the posteroloph and not to the protocone. The size and morphology of $V$. rambliensis sp. nov. are very close to $V$. bacchius from the upper part of unit MN2, from which it may have been derived. The new data allow a better understanding of the relationships within this genus and its biostratigraphy.
\end{abstract}

KEY WORDS: new species; Gliridae; Miocene; Ramblian; Ebro basin; Spain

Francisco J. Ruiz-Sánchez. Area de Paleontologia, Universitat de València, Dr. Moliner s/n, 46100 Burjassot, Spain. francisco.ruiz@uv.es

Xabier Murelaga. Departamento de Estratigrafía y Paleontología, Universidad del País Vasco, Bilbao Aptdo.644, E-48080.xabier.murelaga@ehu.es

Matthijs Freudenthal. Departamento de Estratigrafía y Paleontología, Universidad de Granada, Granada 18071, Spain and Nationaal Natuurhistorisch Museum, Leiden,

now: The Netherlands.mfreuden@ugr.es

Juan C. Larrasoaña. Instituto Geológico y Minero de España, Unidad de Zaragoza 50006, Spain.

jc.larra@igme.es

Miguel Garcés. Grup de Geodinàmica i Anàlisi de Conques, Universitat de Barcelona, Zona Universitaria de Pedralbes, Barcelona 08028, Spain. mgarces@ub.edu 


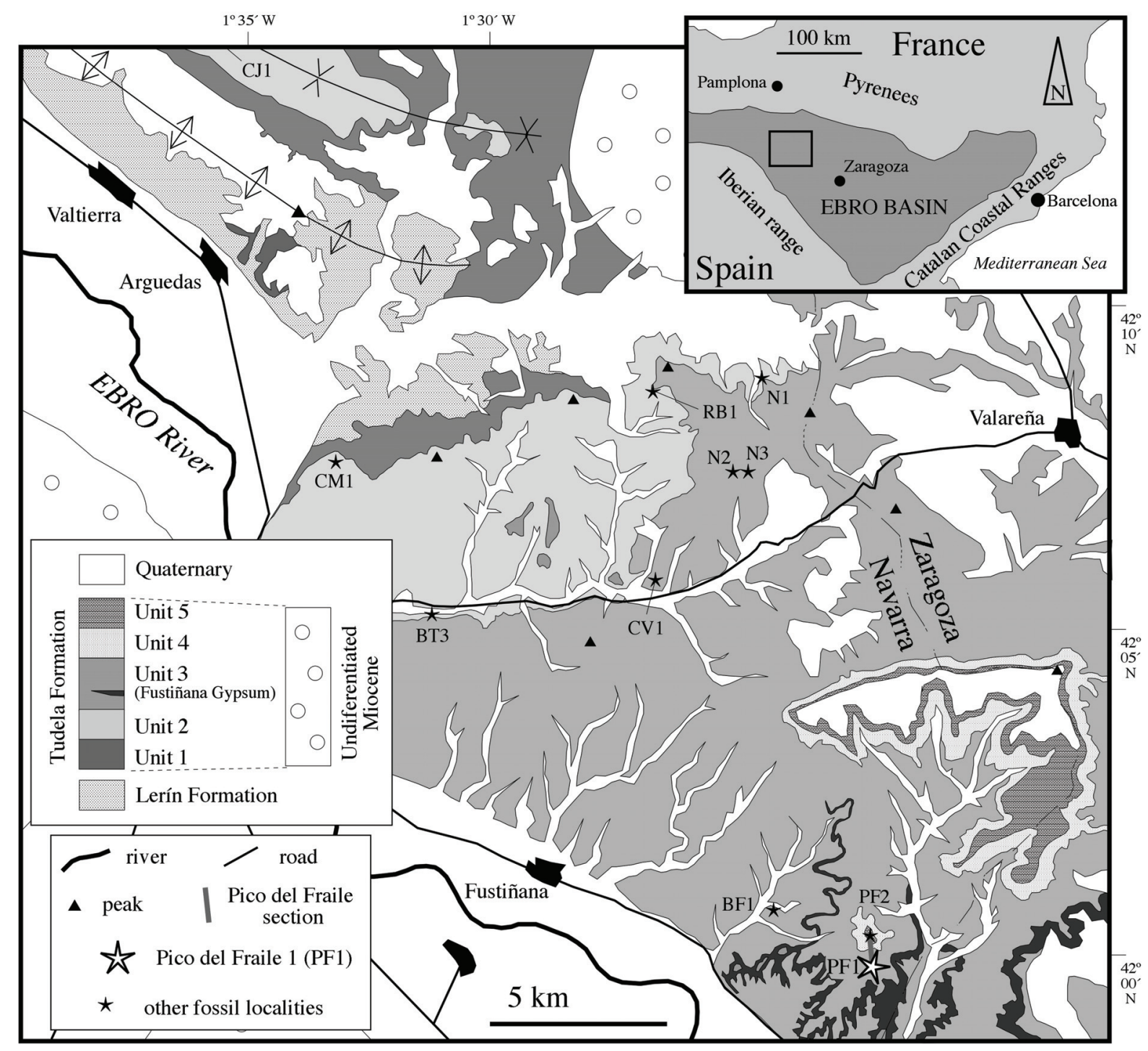

FIGURE 1. Geological map of the continental sediments of the Tudela Formation in the Bardenas Reales de Navarra area, with location of the Pico del Fraile section and the Pico del Fraile 1 (PF1) locality. The location of other fossil localities studied previously by Murelaga (2000) and Murelaga et al. (2004a and 2004b) is also shown.

\section{INTRODUCTION}

In the Tudela Formation of the western part of the Ebro Basin (Figure 1) several mammal localities of Ramblian and Aragonian age are known (Murelaga, 2000; Murelaga et al., 2004a, 2004b; Larrasoaña et al., 2006; Ruiz-Sánchez et al., 2010a, 2010b; Ruiz-Sánchez et al., in press-a). Two of them, Pico del Fraile 1 (PF1, Ebro basin, Eastern Spain, U.T.M.: 30T XM63454650) and Pico del Fraile 2, have yielded remains of the glirid Vasseuromys (Larrasoaña et al., 2006; Ruiz-Sánchez et al., 2010a, 2010b).

Stratigraphically, PF1 is situated $170 \mathrm{~m}$ below PF2 (Figure 2) and it contains: Soricidae indet.,
Ligerimys sp., Peridyromys murinus, Simplomys simplicidens, $V$. rambliensis sp. nov. and Lagomorpha indet. Eucricetodon and Democricetodon are absent. This association led Larrasoaña et al. (2006) to determine its age as Late Ramblian (Early Miocene, MN3, local zone A). In PF2, the presence of Eumyarion cf. weinfurteri, Megacricetodon cf. primitivus, Democricetodon aff. hispanicus, Spermophilinus cf. besana and Vasseuromys cristinae permitted Ruiz-Sánchez et al. (2010b) and Ruiz-Sánchez et al. (in press-a) to assign an Aragonian age to this locality.

The study of Vasseuromys cristinae from PF2 (Ruiz-Sánchez et al., in press-b) made us re-examine the material of this genus in PF1, which allowed 
Tudela Formation composite section

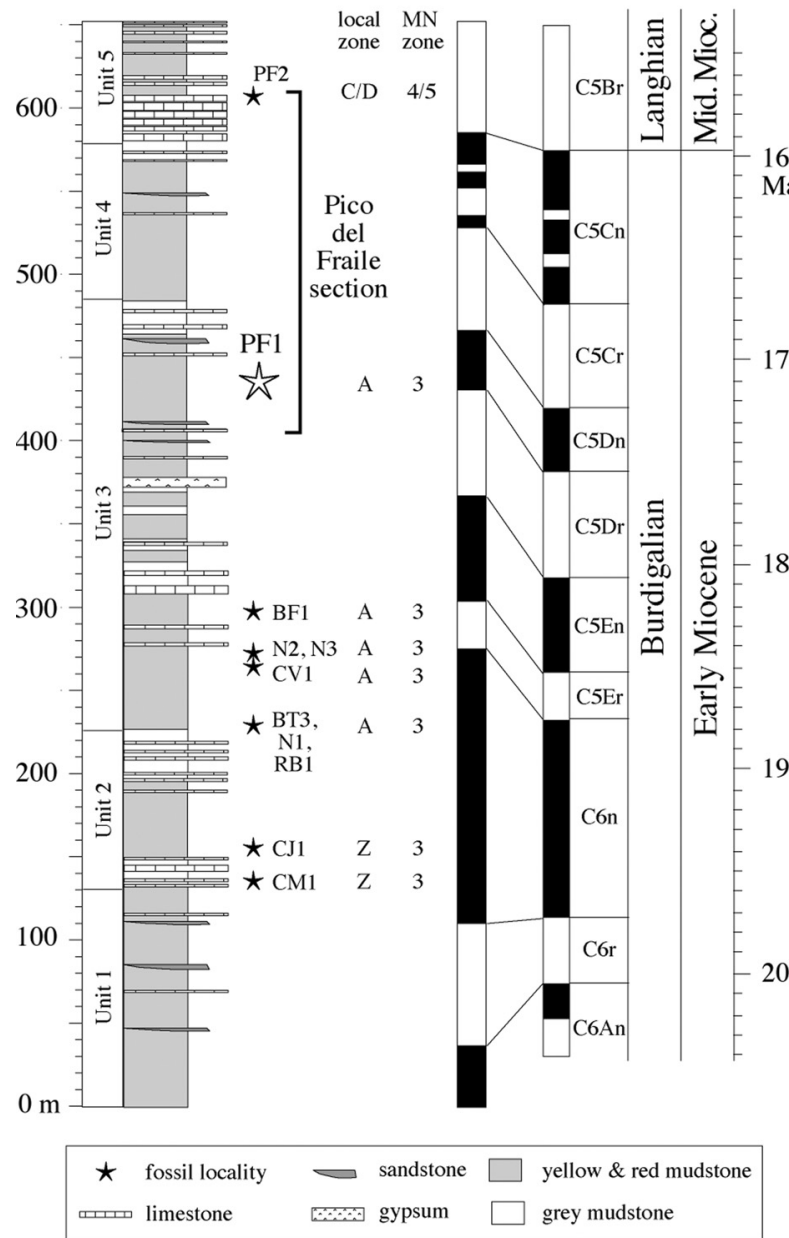

FIGURE 2. Composite lithostratigraphic and magnetostratigraphic logs of the Tudela Formation (see Larrasoaña et al., 2006) and their correlation to the ATNTS2004 of Lourens et al. (2004). The position of locality PF1 is described in this study; for the other fossil localities see Murelaga (2000) and Murelaga et al. (2004a, 2004b).

the recognition of the new species, $V$. rambliensis sp. nov., whose description and phylogeny within the Vasseuromys genus is presented here.

\section{GEOLOGICAL SETTING}

The studied Pico del Fraile section is located in the youngest sediments preserved in the western part of the Ebro basin (Figure 1) in the region of the Bardenas Reales de Navarra (Larrasoaña et al., 2006). The fossil locality PF1 is located in the lower part of the section in the so-called Unit 3 , which is made up of yellow, reddish, brown and grey mudstones with intercalated limestones and sand- stones (Larrasoaña et al. 2006) (Figure 2). Mudstone packages are massive and range between a few centimetres and some metres in thickness. Sandstones appear as thin $(\mathrm{cm})$, sheetlike levels distributed throughout the section and are commonly associated to red and brown mudstones. Limestone beds are typically $<1 \mathrm{~m}$ thick, often massive and bioturbated, and appear clustered within yellow and grey mudstones. These sedimentary facies are similar to those described elsewhere in the central part of the Ebro basin for the Lower and Middle Miocene, when the basin constituted an endorrheic depression at the foothills of the Pyrenees, the Iberian and the Catalan Coastal ranges (Arenas and Pardo, 1999; AlonsoZarza et al., 2002). Thus, yellow, reddish and brown mudstones attest for accumulation in distal fluvial and alluvial muddy flood plains that drained the Pyrenean and Iberian Range margins. Grey mudstones and limestone beds accumulated in palustrine environments located ahead of such distal muddy plains, where ephemeral sheet floods resulted in deposition of thin sandstone beds. The fossil locality PF1 is located in a thin $(20 \mathrm{~cm}$ thick) interval of dark grey mudstones accumulated under palustrine conditions. Magnetostratigraphic data indicate that this fossil locality is located in the lowermost part of chron C5Dn (Larrasoaña et al., 2006), at an approximate age of $17.5 \mathrm{Ma}$ according to the ATNTS2004 (Lourens et al., 2004) (Figure 2).

\section{MATERIAL, METHODS AND ABBREVIATIONS}

Fossils were collected during the field season of 2004 and are provisionally kept in the Department of Stratigraphy and Palaeontology of the University of the Basque Country (UPV/EHU). The nomenclature and methods used in the descriptions of the teeth are that of Freudenthal (2004) (Figure 3). Measurements are in tenths of millimetres and were taken on a Leica $\mathrm{MZ7}_{5}$ binocular microscope, by means of displacement of a mechanical stage, connected to a Sony Magnescale measuring equipment. Concavity profiles were drawn, following Freudenthal and Martín-Suárez (2007b), with a camera lucida mounted on a Wild M5 binocular microscope at 40x magnification.

\section{Abbreviations}

PF1, Pico del Fraile locality 1 (Ebro basin); PF2, Pico del Fraile locality 2 (Ebro basin); MN, European Neogene land mammal units; $\mathbf{L}, \mathbf{W}$, length and width, respectively. 

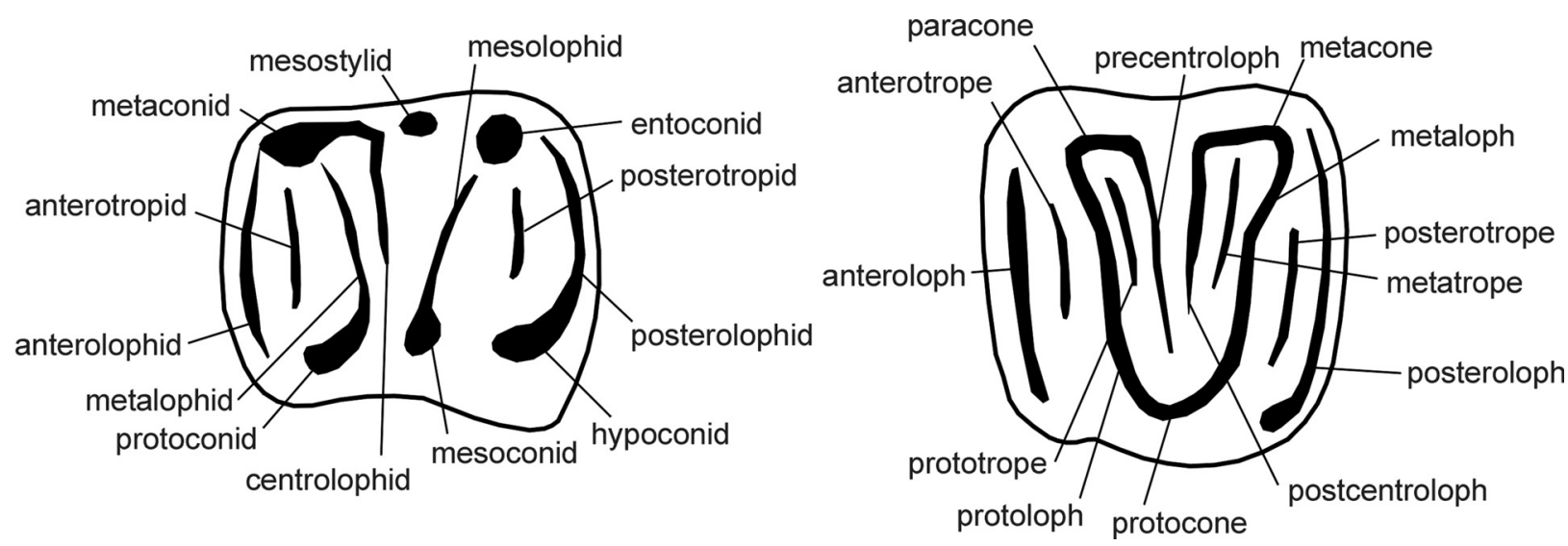

FIGURE 3. Nomenclature of parts of the cheek teeth, adapted after Freudenthal (2004).

\section{Institutional Abbreviations}

UPV/EHU, Universidad del País Vasco/Euskal Herriko Unibertsitatea; SCSIE (UV), Servei Central de Suport a la Investigació Experimental de la Universitat de València.

\section{SYSTEMATIC PALAEONTOLOGY}

Order RODENTIA Bowdich, 1821

Family GLIRIDAE Muirhead, 1819

Genus VASSEUROMYS Baudelot and de Bonis, 1966

Synonymy. Szechenyia Kretzoi, 1978; Ebromys Cuenca, 1985

Type species. Vasseuromys rugosus Baudelot and de Bonis, 1966

\section{Included Species}

Ebromys bergasensis nomen nudum (Bergasa, Ventas 4; MP30; Lacomba, 1988; Cuenca et al., 1992)

Ebromys autolensis (Autol 1, Quel 1, Moncalvillo, Arnedo, Valcarreta 14; MN1; Cuenca, 1985; Lacomba, 1988; Cuenca et al., 1992)

Vasseuromys priscus (Moissac 1, Solothurn, Santa Cilia; MN1; de Bonis, 1973; Engesser, 1976;

Álvarez-Sierra et al., 1991)

Vasseuromys duplex (Harami 1, Harami 2, Harami 3; MN2; Ünay, 1994)

Vasseuromys rugosus (Laugnac, Santa Cilia and Marga 1; MN1 to upper part of MN2; Baudelot and de Bonis, 1966; de Bonis, 1973; Álvarez-Sierra et al., 1991; Cuenca et al., 1992)

Ebromys bacchius (Fuenmayor 2, Abuelo 1, Chalamera, Islallana and Miranda de Arga 3A; upper part of MN2; Martínez-Salanova, 1987; Cuenca et al., 1992)

Vasseuromys elegans (Stubersheim 3; MN3; Wu, 1993)

Vasseuromys cristinae (Pico del Fraile 2, MN4 or MN5; Ruiz-Sánchez et al., in press-b)

Vasseuromys aff. multicrestatus (SC 109, MN5; Agustí et al., 2011)

Vasseuromys pannonicus (Széchenyi hill,

Eichkogel, Kohfidisch, Lefkon; MN10/MN11; Armour-Brown et al., 1977; Kretzoi ,1978; DaxnerHöck and de Bruijn, 1981; de Bruijn, 1989; DaxnerHöck and Höck, 2009)

The genus Vasseuromys was first described in the localities of Laugnac and Moissac I (Baudelot and de Bonis, 1966; de Bonis, 1973) for Gliridae of medium size with concave occlusal surface and a tendency of the molar cusps to extend longitudinally.

The genus has a time range from Late Oligocene to Early-Middle Miocene (zones MP30 to MN4-MN5) and reappears in the Late Miocene (zone MN11) (Lacomba, 1988; Daams, 1999).

An older occurrence, V. moyai, was proposed in the Spanish MP25 locality of Sineu (Hugueney and Adrover, 1990), but this material was reassigned to Oligodyromys by Freudenthal and Martín-Suárez (2007a), based on Hugueney and Adrover (1990) who thought it to be derived from a species close to Oligodyromys planus.

\section{Vasseuromys rambliensis sp. nov.}

Figure 4.1-4.18

v. 2006 Vasseuromys sp.; Larrasoaña, Murelaga and Garcés, not figured 
Derivatio nominis: This species is named after the Ramblian age.

Holotype: PF1-15, isolated right $\mathrm{m} 1$ housed in the Department of Stratigraphy and Palaeontology of the University of the Basque Country.

Referred material: 3 d4 (PF1-29; PF1-30; PF133), 2 p4 (PF1-28; PF1-31), 2 m1 (PF1-15; PF121), 6 m2 (PF1-8; PF1-12; PF1-13; PF1-14; PF116; PF1-20), 5 m3 (PF1-9; PF1-10; PF1-11; PF118; PF1-19), 5 D4 (PF1-23; PF1-24; PF1-25; PF126; PF1-27), 5 P4 (PF1-34; PF1-35; PF1-37; PF138; PF1-39), 3 M1 (PF1-2; PF1-4; PF1-6), 6 M2 (PF1-1; PF1-3; PF1-5; PF1-7; PF1-57; PF1-58), 1 M3 (PF1-36).

Type locality: Pico del Fraile 1 (PF1), Upper Ramblian (MN3, zone A), $17.5 \mathrm{Ma}$ (Lower Miocene), Ebro basin, Spain. U.T.M.: 30T XM (X: 634; Y: 4651)

Occurrence: Pico del Fraile 1 (PF1), Ebro basin (Spain).

Diagnosis: Medium/large-sized Vasseuromys. Lower molars with four extra ridges. Anterotropid poorly developed (nearly non-existent) in all $\mathrm{m} 1$ and half of $\mathrm{m} 2$, and of medium size in the rest of $\mathrm{m} 2$ and all $\mathrm{m} 3$. Inside the trigone of the upper molars there are between one and three reduced extra ridges, whereas outside the trigone only the M1 (one out of two specimens) has a short extra ridge (anterotrope). In M1-2 the metaloph is connected to the posteroloph and not to the protocone.

Differential diagnosis: Differing from $V$. autolensis, V. priscus, V. rugosus, V. bacchius, V. elegans and $V$. pannonicus in: four extra ridges in m1-2-3 and posterotropid always single. Differing from all other Vasseuromys species, except $V$. cristinae, in: complete absence of endoloph in M1-2. Differing from all other Vasseuromys species in: metaloph not connected to the protocone and high or low connected to the posteroloph. V. rambliensis sp. nov. is smaller than $V$. bacchius and larger than the rest of Vasseuromys species.

Measurements: See Table 1.

\section{Description}

d4. Anterolophid connected to the protoconid. The centrolophid is short and free-ending (1), or long and fused to the protoconid (1). The labial cusps are not longitudinally elongated towards the anterior part of the tooth. Two or three extra ridges are present. The specimens show a very short extra ridge between centrolophid and metalophid and a posterotropid (Figure 4.1). In one out of two speci- mens there is one additional extra ridge in the central valley.

p4. Anterolophid connected to protoconid. A short anterotropid is connected to the anterolophid. Metalophid curved forward and connected to the metaconid. The centrolophid is of medium size. Mesolophid and posterolophid connected to the entoconid. The single posterotropid is not connected to the main ridges.

m1. The anterolophid and the metalophid are connected to the protoconid and metaconid, respectively, at a high level. The centrolophid is double and does not reach the labial border of the tooth. The anterior centrolophid is of medium-long size, and the posterior one is of medium size. Both ridges are labially connected (2) or they end free. Mesolophid connected to the entoconid. Posterotropid single, long and low connected to the anterolingual part of the posterolophid. Four extra ridges: a very short anterotropid attached to the anterolophid; one of medium size between metalophid and centrolophid; a second centrolophid and a posterotropid. The second centrolophid is lingually attached to the anterior centrolophid.

m2. In unworn specimens the anterolophid is not connected to the protoconid. The metalophid is connected to metaconid. The centrolophid is of medium size and ends free. Mesolophid connected to entoconid. The posterolophid is not connected to the mesoconid. Four extra ridges are present: a very short (2) (Figures 4.5, 4.7) or short (2) (Figure 4.6) anterotropid; one between metalophid and anterior centrolophid, which is very short (1) (Figure 4.6), short (1), of medium size (1) or long (1) (Figure 4.7); a second centrolophid of medium size and a posterotropid, which is not connected to the posterolophid. The endolophid is continuous (3) (Figure 4.7) or interrupted (1) (Figures 4.5, 4.6).

m3. Anterolophid connected (1) (Figure 4.9) or not connected (3) (Figures 4.8, 4.10) to the protoconid. Metalophid connected to metaconid. Centrolophid long (1) and fused to the anterior prolongation of the mesoconid (Figure 4.8), or of medium size (3) and ending free (Figures 4.9, 4.10). Mesolophid connected to entoconid. The labial part of the posterolophid is longitudinally elongated and separated from the mesoconid. There are four extra ridges: an anterotropid, one between metalophid and centrolophid, a second centrolophid and a posterotropid. Generally the extra ridges in the anterior valley are shorter than the central and posterior ones (Figure 4.8). The endolophid is nearly 

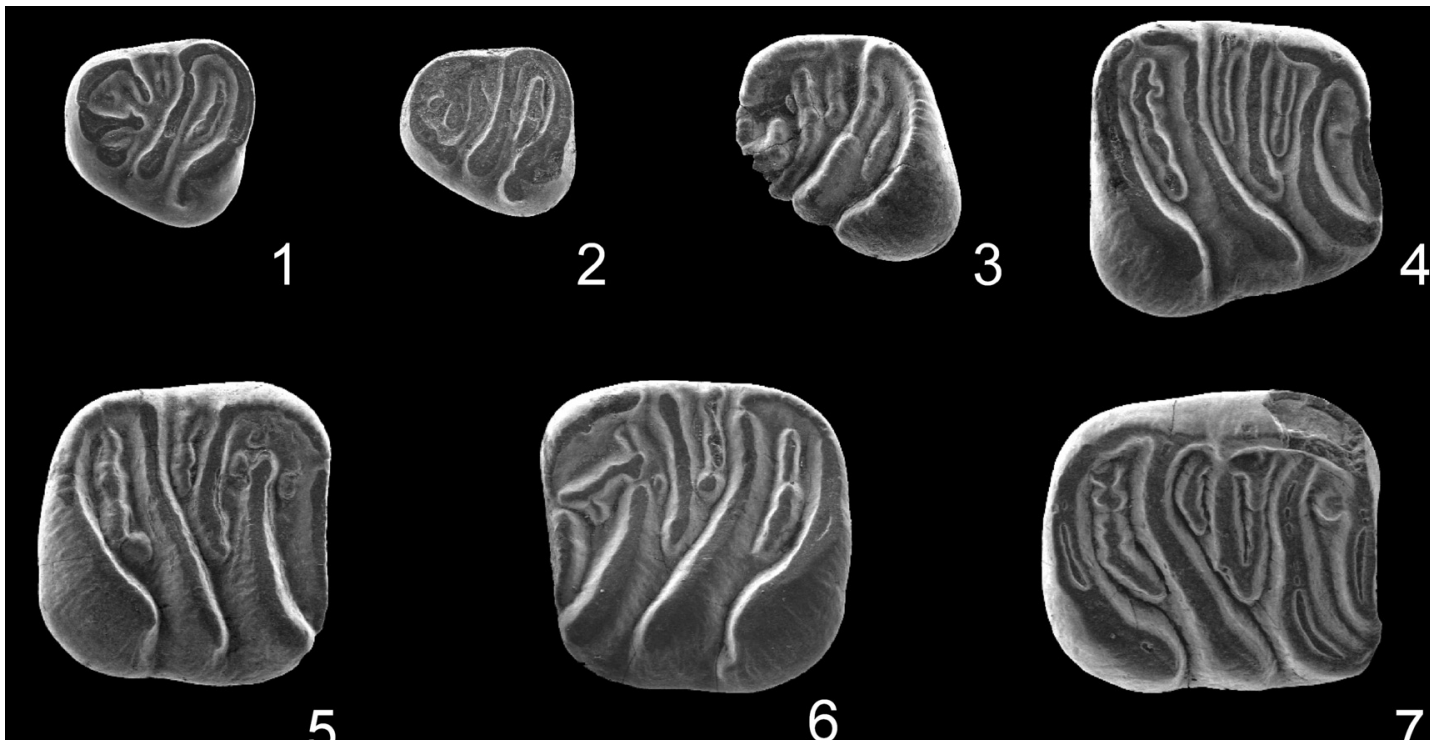

5
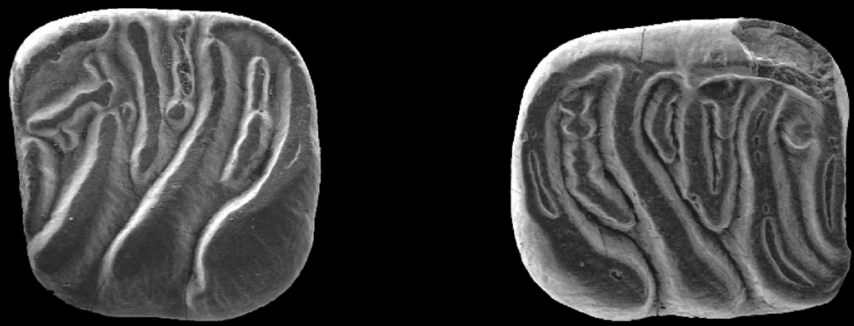

6
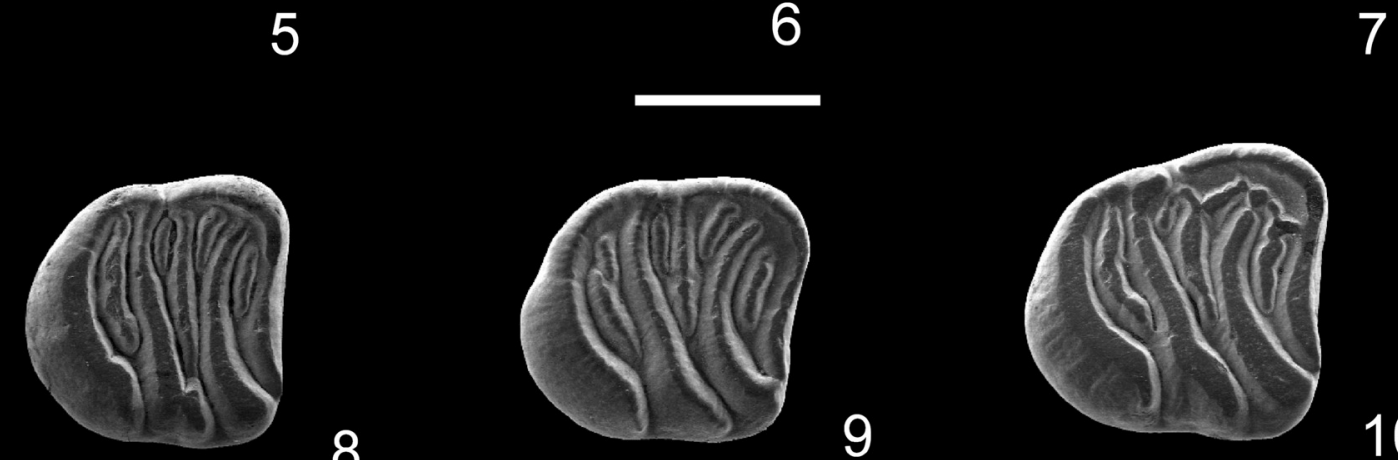

8

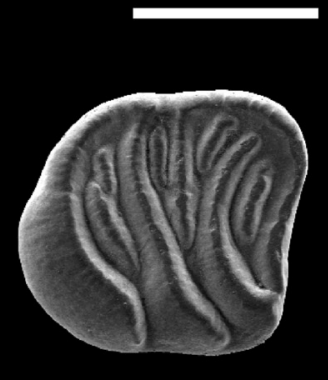

9

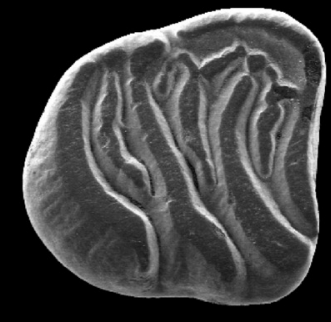

10
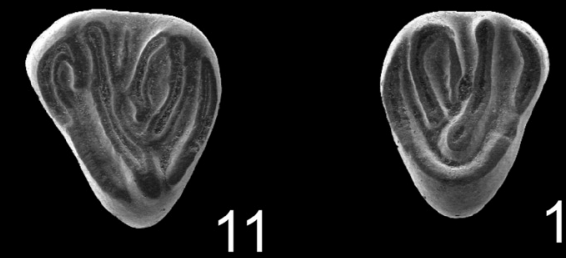

11
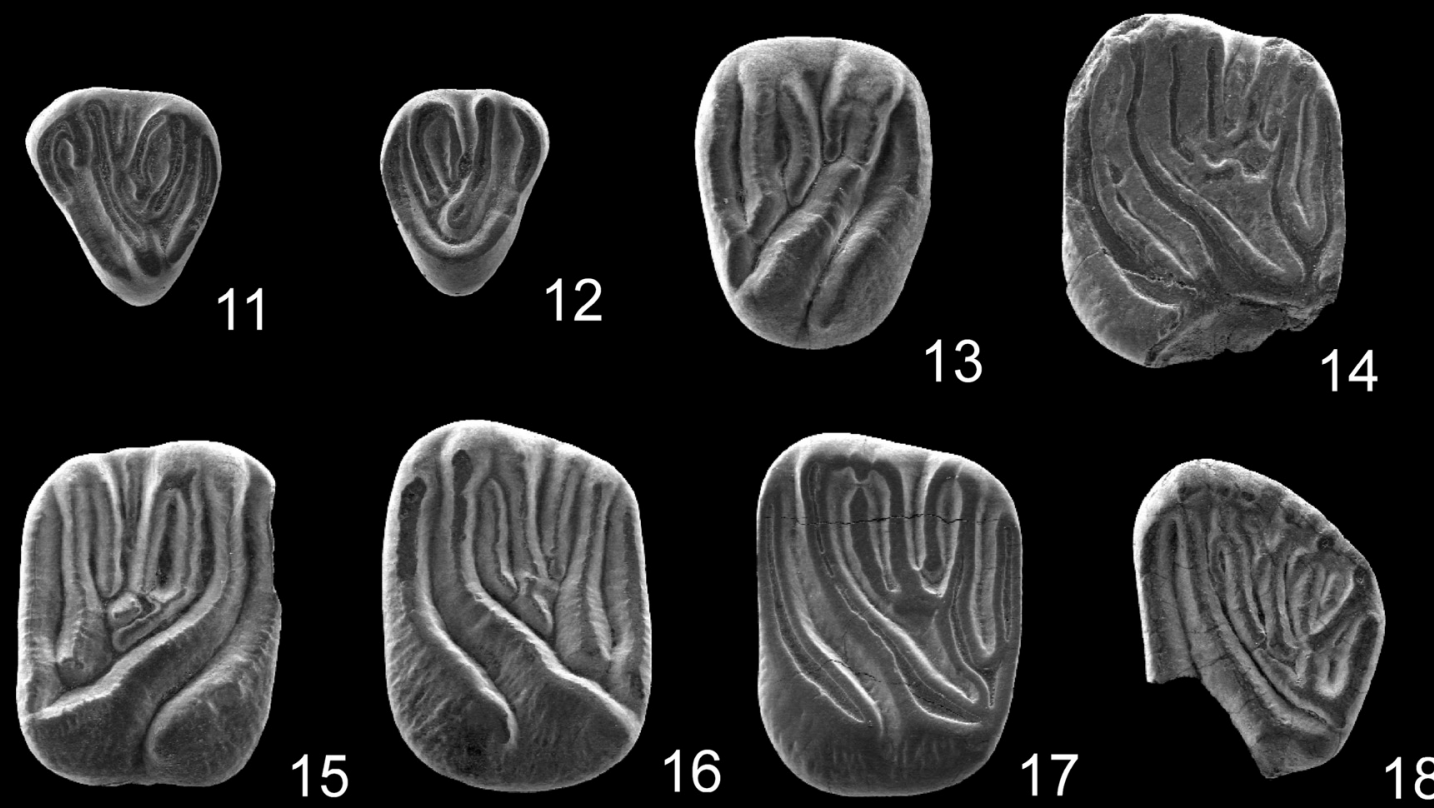

FIGURE 4. Vasseuromys rambliensis sp. nov. from PF1, Ebro basin, Spain. 1, PF1 29, left d4; 2, PF1 30, left d4; 3 , PF1 28, left p4; 4, PF1 15 (holotype), right m1; 5, PF1 8, right m2; 6, PF1 12, left m2; 7, PF1 16, right m2; 8, PF1 9, right m3; 9, PF1 10, right m3; 10, PF1 11, right m3; 11, PF1 24, left D4; 12, PF1 27, right D4; 13, PF1 37, right P4; 14 , PF1 2, left M1; 15, PF1 1, right M2; 16, PF1 3, left M2; 17, PF1 58, left M2; 18, PF1 36, left M3. Scale bar equals 1 $\mathrm{mm}$. 
TABLE 1. Measurements in millimetres of the lower and upper teeth of $V$. rambliensis sp. nov. from PF1.

\begin{tabular}{cccccc} 
Element & Parameter & n & min. & mean & Max. \\
\hline d4 & L & 2 & 0.91 & 0.94 & 0.96 \\
p4 & W & 2 & 0.83 & 0.88 & 0.93 \\
& L & 1 & & 1.10 & \\
m1 & W & 1 & & 1.09 & \\
& L & 2 & 1.24 & 1.30 & 1.36 \\
m2 & W & 1 & & 1.33 & \\
& L & 5 & 1.40 & 1.46 & 1.51 \\
m3 & W & 5 & 1.34 & 1.42 & 1.49 \\
& L & 5 & 1.27 & 1.35 & 1.44 \\
D4 & W & 5 & 1.22 & 1.28 & 1.36 \\
& L & 4 & 0.81 & 0.87 & 0.94 \\
P4 & W & 4 & 0.94 & 0.99 & 1.05 \\
& L & 3 & 1.04 & 1.07 & 1.10 \\
M1 & W & 2 & 1.34 & 1.35 & 1.36 \\
& L & 1 & & 1.40 & \\
M2 & W & 1 & & 1.67 & \\
& L & 4 & 1.29 & 1.40 & 1.49 \\
M3 & W & 4 & 1.69 & 1.78 & 1.83 \\
& $\mathrm{~L}$ & 1 & & 1.25 & \\
& W & 1 & & 1.40 & \\
& & & & &
\end{tabular}

continuous. The posterotropid is lingually connected to the posterolophid.

D4. Anteroloph low (2) (Figure 4.11) or high (2) (Figure 4.12) connected to the protocone and high connected to the paracone. Protoloph curved, not connected to the protocone (1) (Figure 4.12) or connected (3). Metaloph oblique and connected to the lingual end of the protoloph, not directly to the protocone. The postcentroloph is larger than the precentroloph. Two specimens do not have a precentroloph (Figure 4.12). In two out of five specimens there are two very short extra ridges inside the trigone. Posteroloph connected to metacone and protocone. In two out of five teeth, anteroloph, protocone and posteroloph form a continuous ridge (Figure 4.12).

P4. Anteroloph not connected to the protocone. Labially the anteroloph is low connected to the paracone. Protoloph connected to the protocone. Metaloph connected to the lingual part of the posteroloph or ending lingually free. Precentroloph short. Postcentroloph of medium size and low connected to the lingual end of the metaloph. The extra ridges are reduced to a very short metatrope and in one out of two unworn specimens a very short ridge between pre- and postcentroloph. The posteroloph is long and low connected to the protocone.

M1. The anteroloph is long and not connected to the protocone. The centrolophs are long and the precentroloph is longer than the postcentroloph. The metaloph is transverse and connected to the posteroloph. There are two or three extra ridges inside the trigone: a prototrope, another one between precentroloph and postcentroloph and a reduced metatrope in one case. Outside the trigone, one out of two specimens has a very short anterotrope. A shallow furrow separates the labial end of the posteroloph from the metacone.

M2. Anteroloph separated from the paracone by a shallow furrow. The anteroloph is long and not connected to the protocone. The paracone is divided into two cusps (2) (Figure 4.16) or it is one single and relatively big cusp (2) (Figure 4.17). The centrolophs are of medium size, being the precentroloph longer than postcentroloph. There are one to three extra ridges inside the trigone, generally one or two: a long prototrope, a short (one out of six) ridge between precentroloph and postcentroloph (Figure 4.15) (absent in five out of six specimens, Figures 4.16, 4.17) and a rare metatrope (one out of six). There are no extra ridges outside the trigone. The metaloph is transverse, separated from the protocone by a wide furrow and connected to the posteroloph (Figure 4.15-4.17). The posteroloph is connected to the protocone (5) or not connected (1) and separated from the metacone by a furrow.

M3. Anteroloph connected to the paracone. The protoloph and the anterior centroloph are long and very oblique. Three very short extra ridges are present inside the trigone. Outside the trigone there are no extra ridges. The connections between centrolophs and extra ridges form an irregular pattern. The labial border is marked by eight little cusps. Posteroloph very short and connected to protocone and metacone.

\section{DISCUSSION}

Since the description of Vasseuromys by Baudelot and de Bonis (1966) new data have contributed to a better knowledge of the systematics, biostratigraphy and palaeogeography of this genus. Nevertheless, many questions remain open. The assemblage of Vasseuromys from PF1 provides new information on the taxonomic position, biostratigraphy and phylogeny of the genus. The presence of several localities with assemblages of this genus in the same basin (Cuenca, 
1985; Martínez-Salanova, 1987; Lacomba, 1988; Álvarez-Sierra et al., 1991; Cuenca et al., 1992; Larrasoaña et al., 2006; Ruiz-Sánchez et al., 2010a; Agustí et al., 2011), or even in the same section in stratigraphic superposition, provides unique opportunities for comparison. In the Pico del Fraile section at least three assemblages with Vasseuromys remains have been found: PF1 and PF2 (Larrasoaña et al., 2006; Ruiz-Sánchez et al., 2010) and, recently, Sancho Abarca 5 (SA5). In the following the main metric, morphological, biostratigraphic and phylogenetic features of the Vasseuromys assemblage from PF1 are analyzed and compared with the other occurrences of the genus.

\section{Biometry}

Vasseuromys bacchius is a large-sized Vasseuromys; the other species form a small-sized group. The size of $V$. rambliensis sp. nov. from PF1 is intermediate between the two groups, or it covers the lower part of the range of $V$. bacchius (Figures 5,6$)$. This is especially evident in length and width of $\mathrm{m} 2$.

\section{Concavity}

Strong concavity is one of the diagnostic features of Vasseuromys mentioned by Baudelot and de Bonis (1966). The scarce material of the type species of the genus, V. rugosus, has a strong concavity, but this character is not constant in all species of the genus.

Following the method proposed by Freudenthal and Martín-Suárez (2007b) to measure the concavity of glirid molars, we drew 22 profiles in anterior and posterior view of the available specimens ( $2 \mathrm{~m} 1,4 \mathrm{~m} 2,1 \mathrm{M} 1$ and $5 \mathrm{M} 2)$ of $\mathrm{V}$. rambliensis sp. nov. We focus on the values of $h / r$, where $h$ is the maximum depth of the concavity and $r$ the radius of the best-fitting circle (Table 2 ). Mean values are calculated when more than one specimen is available, and the data are compared with those of $V$. cristinae (Ruiz-Sánchez et al., in press-b) and $V$. autolensis and $V$. duplex (Freudenthal and Martín-Suárez, 2007b). Comparison of the data for $\mathrm{C}$ $(\mathrm{h} / \mathrm{r})$ (Table 3; Figure 7) shows that $\mathrm{V}$. rambliensis sp. nov. is weakly concave and $V$. cristinae, moderately concave, and therefore, the latter one is the most concave of the four compared species.

\section{Morphology}

Lower molars. The number of ridges in Vasseuromys shows a great variability. According to RuizSánchez et al. (in press-b), the lower molars of $V$. autolensis, V. rugosus, V. bacchius, V, duplex and
$V$. pannonicus generally have between nine and 11 ridges whereas $V$. priscus and $V$. elegans have between eight and nine. Vasseuromys cristinae from PF2 and V. aff. multicrestatus from SC 109 always have nine ridges in the lower dentition.

Vasseuromys rambliensis sp. nov. has nine ridges in the lower molars: four main ridges, the centrolophid and four extra ridges, whereas the upper molars have between seven and 10 ridges: four main ridges, two centrolophs and between one and four extra ridges. While the M1 has between eight and 10 ridges, the M2 has between seven and nine. The variability in the total number of ridges in the M3 can not be evaluated because of the scarcity of material.

The ridge pattern of the lower molars of $V$. rambliensis sp. nov. is similar to that of $V$. bacchius from Fuenmayor 2: centrolophid and posterotropid not exceeding $3 / 4$ of the tooth width (only one m3 out of 13 lower molars of PF1 has a long centrolophid connected to the mesoconid) and strong length reduction of the extra ridges of the lower molars (clearly more reduced in V. rambliensis $\mathrm{sp}$. nov.), especially the anterotropid. In V. rambliensis $\mathrm{sp}$. nov., this last ridge is strongly reduced in both $\mathrm{m} 1$ (forming a little protuberance of the posterior side of the anterolophid). The anterotropid is also strongly reduced in three out of six $\mathrm{m} 2$ and shows a medium-large length in the five $\mathrm{m} 3$. The extra ridges, especially the anterotropid, in the lower molars of $V$. rambliensis sp. nov. are much shorter than in most species of the genus. Only $V$. priscus (Álvarez-Sierra et al., 1991) shows extra ridges with a similar size, though still less reduced than in V. rambliensis sp. nov.

Generally, the Vasseuromys species, except for $V$. priscus and $V$. bacchius, have a long centrolophid, sometimes fused to the mesoconid. In $\mathrm{V}$. rambliensis sp. nov. the centrolophid is of medium size, and generally has a free end (not connected to the mesoconid). Only in the $\mathrm{m} 1$ the anterior centrolophid is connected to the posterior centrolophid. The degree of development and connections of the centrolophid in PF1 is very similar to that found in V. bacchius from Fuenmayor 2.

On the other hand, except for $V$. priscus, $V$. elegans, V. cristinae and $V$. aff. multicrestatus the Vasseuromys species usually have more than one (2-3) posterotropids (Ruiz-Sánchez et al., in pressb). Vasseuromys cristinae and $V$. aff. multicrestatus are the only species with a single posterotropid, with the exception of the lower molars of $V$. rambliensis sp. nov., which also show a single poster- 


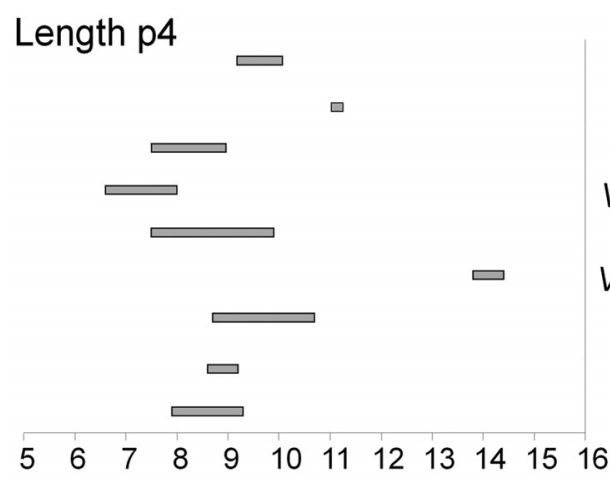

V. cristinae (PF2)

V. rambliensis (PF1)

V. pannonicus (Eichkogel)

$V$. elegans (Stubersheim 3)

V. duplex (Harami 1)

V. bacchius (Fuen Mayor 2)

V. rugosus (Sta. Cilia)

V. priscus (Sta. Cilia)

V. autolensis (Autol 1)

Width p4
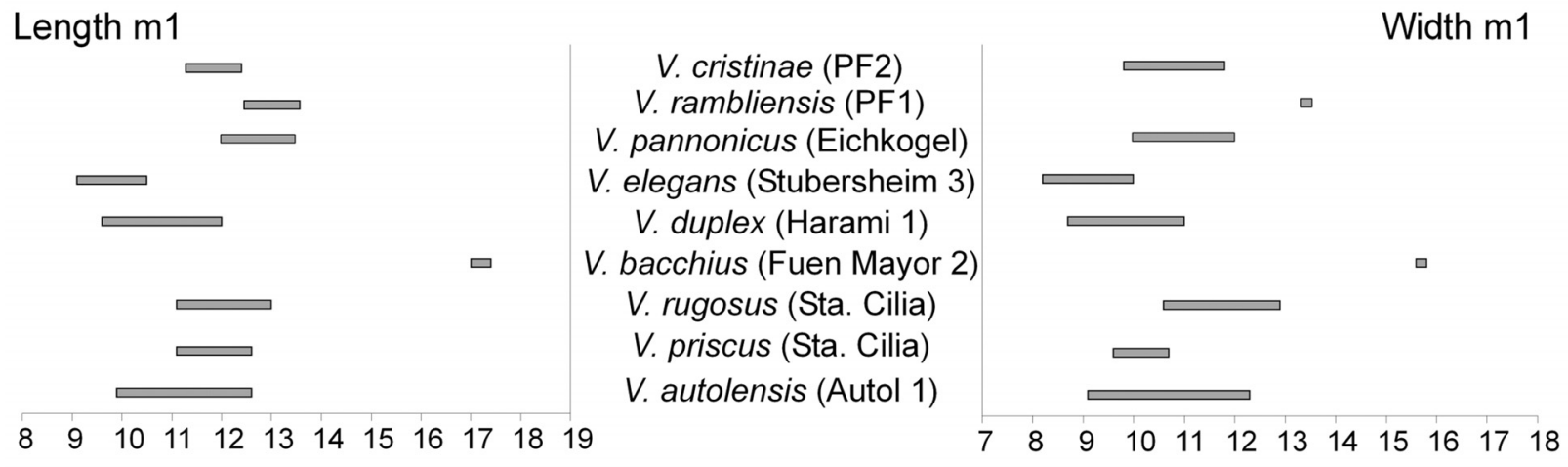

Length $\mathrm{m} 2$

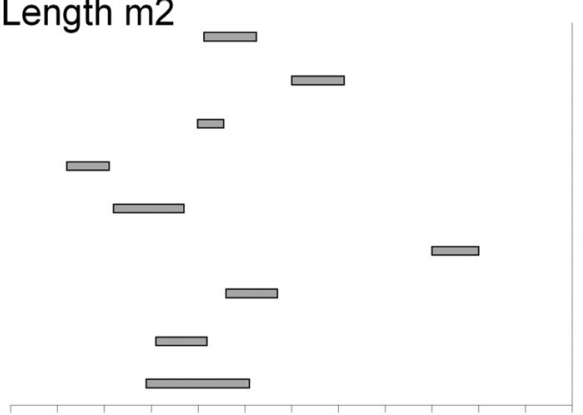
V. cristinae (PF2)
V. rambliensis (PF1)
V. pannonicus (Eichkogel)
$V$. elegans (Stubersheim 3)
V. duplex (Harami 1)
V. bacchius (Fuen Mayor 2)
V. rugosus (Sta. Cilia)
V. priscus (Sta. Cilia)
V. autolensis (Autol 1)

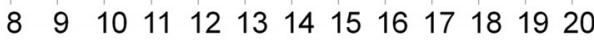
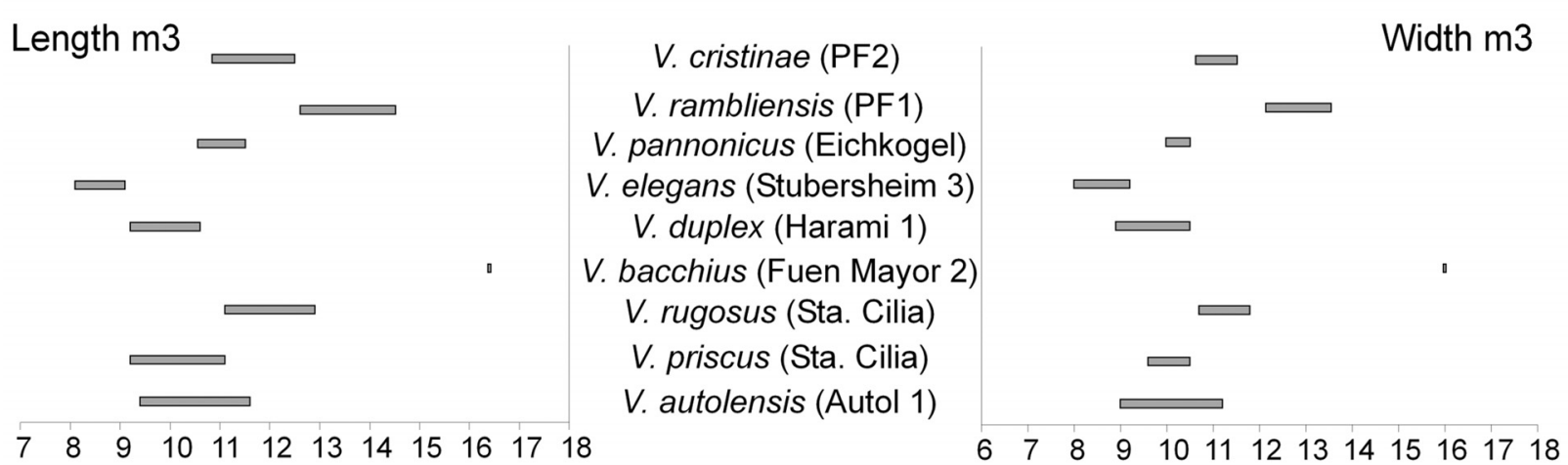

$\begin{array}{llllllllllll}7 & 8 & 9 & 10 & 11 & 12 & 13 & 14 & 15 & 16 & 17 & 18\end{array}$

FIGURE 5. Ranges of variation of length and width (tenths of millimeters) of the lower molars of $V$. rambliensis sp. nov. from PF1, V. pannonicus from Eichkogel, $V$. elegans from Stubersheim 3, V. duplex from Harami 1, V. bacchius from Fuenmayor 2, $V$. rugosus from Santa Cilia and Laugnac, $V$. priscus from Santa Cilia and $V$. autolensis from Autol 1. 

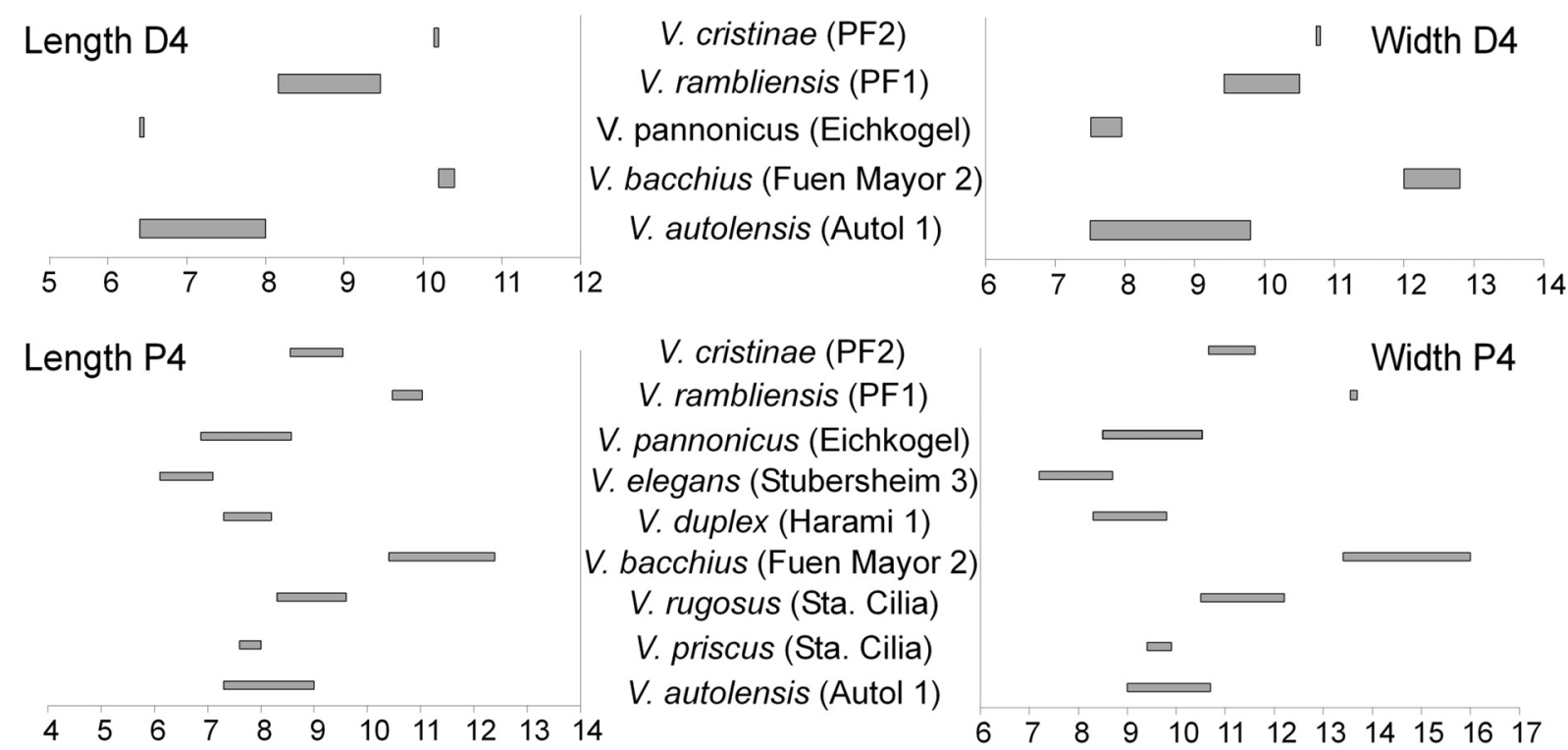

V. bacchius (Fuen Mayor 2)

V. rugosus (Sta. Cilia)

V. priscus (Sta. Cilia)

V. autolensis (Autol 1)
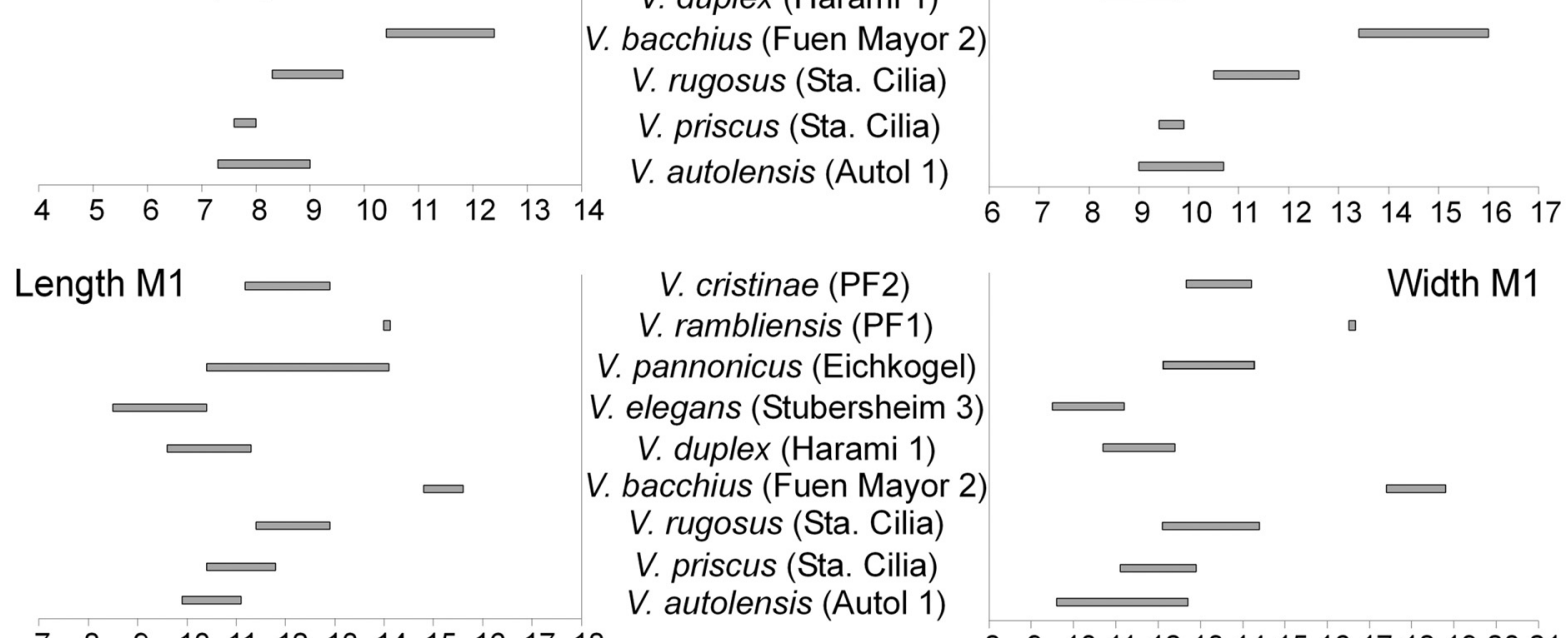

$\begin{array}{llllllllllll}7 & 8 & 9 & 10 & 11 & 12 & 13 & 14 & 15 & 16 & 17 & 18\end{array}$

$8 \quad 9 \quad 101112131415161718192021$

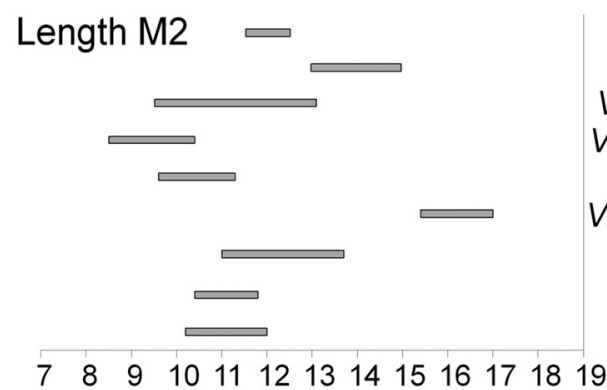

V. cristinae (PF2)

V. rambliensis (PF1)

$\checkmark$. pannonicus (Eichkogel)

$V$. elegans (Stubersheim 3)

V. duplex (Harami 1)

V. bacchius (Fuen Mayor 2)

V. rugosus (Sta. Cilia)

V. priscus (Sta. Cilia)

V. autolensis (Autol 1)

$\begin{array}{lllllllllllll}7 & 8 & 9 & 10 & 11 & 12 & 13 & 14 & 15 & 16 & 17 & 18 & 19\end{array}$
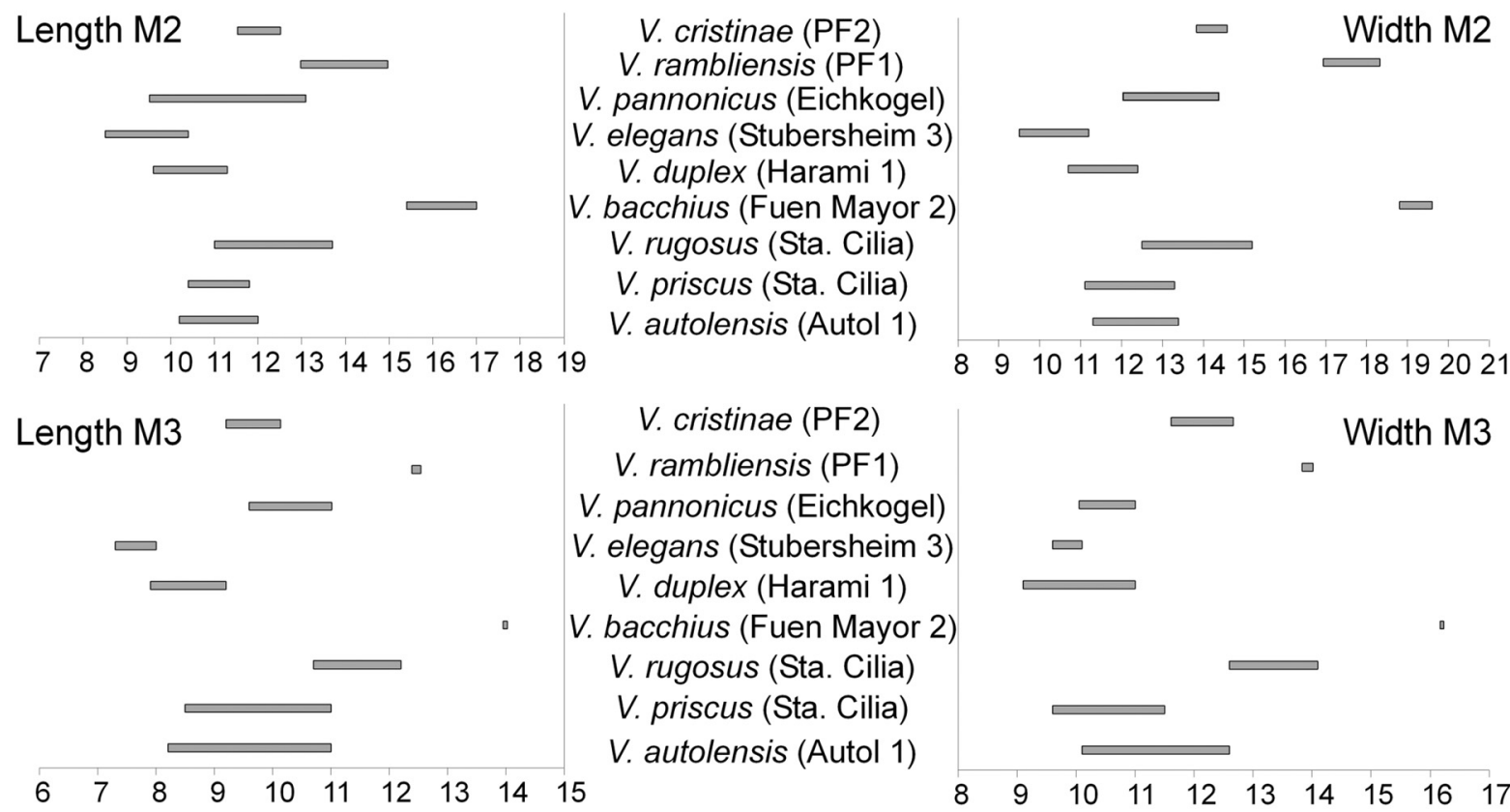

V. cristinae (PF2)

V. rambliensis (PF1)

$8 \quad 9 \quad 101112131415161718192021$

V. pannonicus (Eichkogel)

$V$. elegans (Stubersheim 3)

V. duplex (Harami 1)

V. bacchius (Fuen Mayor 2)

V. rugosus (Sta. Cilia)

V. priscus (Sta. Cilia)

V. autolensis (Autol 1)

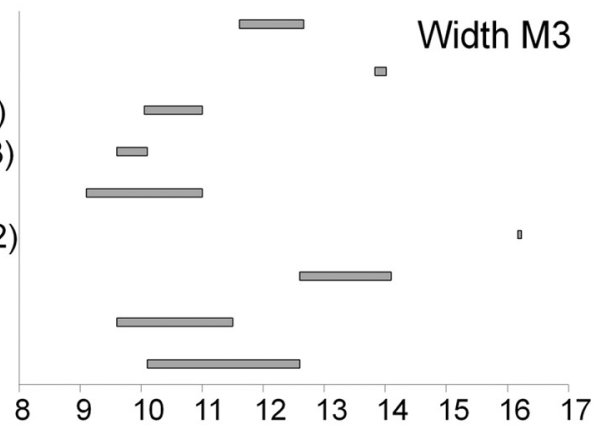

FIGURE 6. Ranges of variation of length and width (tenths of millimeters) of the upper molars of $V$. rambliensis sp. nov. from PF1, V. pannonicus from Eichkogel, V. elegans from Stubersheim 3, V. duplex from Harami 1, V. bacchius from Fuenmayor 2, V. rugosus from Santa Cilia and Laugnac, V. priscus from Santa Cilia and Moissac 1 and V. autolensis from Autol 1. 
TABLE 2. Measurement values of concavity in $V$. rambliensis sp. nov. of PF1 (12 specimens; 2 m1 inf. ant., 1 m1 inf. post., $4 \mathrm{~m} 2$ inf. ant., $4 \mathrm{~m} 2$ inf. post., $1 \mathrm{~m} 1$ sup. ant., $1 \mathrm{~m} 1$ sup. post., $4 \mathrm{~m} 2$ sup. ant. and $5 \mathrm{~m} 2$ sup. post. profiles) and comparison with $V$. autolensis from Autol 1 (1 specimen) and $V$. duplex from Harami 1 (1 specimen). For more detail see Freudenthal and Martín-Suárez (2007b). Abbreviations: S, surface of concavity profile; w, maximum width of the molar as seen in the profile; $\mathbf{b}$, distance between $\mathrm{x}$ and $\mathrm{y} ; \mathbf{h}$, maximum depth of the concavity; $\mathbf{r}$, radius of the best-fitting circle.

\begin{tabular}{|c|c|c|c|c|c|c|c|c|c|c|c|c|}
\hline m1 inf. ant. & Surf & $\mathbf{w}$ & b & $\mathbf{h}$ & $S / b$ & $h / b$ & $\mathbf{r}$ & $h / r$ & $b / 2 r$ & $w / 2 r$ & skewness & mean dev \\
\hline V. rambliensis mean & 0.60 & 10.00 & 5.55 & 0.24 & 0.11 & 0.04 & 3.94 & 0.09 & 0.68 & 1.27 & 71.65 & 4.15 \\
\hline V. cristinae mean & 1.24 & 10.00 & 6.95 & 0.38 & 0.18 & 0.06 & 5.30 & 0.07 & 0.66 & 0.95 & 50.90 & 0.34 \\
\hline V. duplex & 1.98 & 10.00 & 7.01 & 0.52 & 0.28 & 0.07 & 10.61 & 0.05 & 0.33 & 0.47 & 61.4 & 0.05 \\
\hline m1 inf. post. & Surf & w & $\mathrm{b}$ & $\mathrm{h}$ & $\mathrm{S} / \mathrm{b}$ & $\mathrm{h} / \mathrm{b}$ & $r$ & $\mathrm{~h} / \mathrm{r}$ & $\mathrm{b} / 2 \mathrm{r}$ & $w / 2 r$ & skewness & mean dev \\
\hline V. rambliensis & 1.42 & 9.96 & 6.56 & 0.39 & 0.22 & 0.06 & 4.97 & 0.08 & 0.66 & 1.00 & 44.6 & 0.20 \\
\hline V. cristinae mean & 2.46 & 10.00 & 6.41 & 0.77 & 0.38 & 0.12 & 4.13 & 0.18 & 0.78 & 1.22 & 49.73 & 0.14 \\
\hline V. duplex & 2.96 & 10.00 & 7.53 & 0.71 & 0.39 & 0.09 & 8.84 & 0.08 & 0.43 & 0.57 & 54.3 & 0.06 \\
\hline $\mathrm{m} 2$ inf. ant. & Surf & w & $\mathrm{b}$ & $\mathrm{h}$ & $\mathrm{S} / \mathrm{b}$ & $\mathrm{h} / \mathrm{b}$ & $r$ & $\mathrm{~h} / \mathrm{r}$ & $\mathrm{b} / 2 \mathrm{r}$ & $w / 2 r$ & skewness & mean dev \\
\hline V. rambliensis mean & 1.94 & 10.00 & 6.52 & 0.61 & 0.30 & 0.10 & 4.39 & 0.14 & 0.75 & 1.15 & 54.98 & 0.19 \\
\hline V. cristinae mean & 2.27 & 10.00 & 6.62 & 0.66 & 0.34 & 0.10 & 4.80 & 0.14 & 0.69 & 1.05 & 67.28 & 0.19 \\
\hline V. autolensis & 2.92 & 10.00 & 7.09 & 0.77 & 0.41 & 0.11 & 7.44 & 0.10 & 0.48 & 0.67 & 65.8 & 0.09 \\
\hline m2 inf. post. & Surf & $w$ & $\mathrm{~b}$ & $\mathrm{~h}$ & $\mathrm{~S} / \mathrm{b}$ & $\mathrm{h} / \mathrm{b}$ & $r$ & $\mathrm{~h} / \mathrm{r}$ & $\mathrm{b} / 2 \mathrm{r}$ & $w / 2 r$ & skewness & mean dev \\
\hline V. rambliensis mean & 1.49 & 10.00 & 6.23 & 0.40 & 0.23 & 0.06 & 4.51 & 0.09 & 0.69 & 1.12 & 70.33 & 0.23 \\
\hline V. cristinae mean & 2.33 & 10.00 & 6.39 & 0.65 & 0.36 & 0.10 & 4.34 & 0.15 & 0.74 & 1.17 & 69.73 & 0.20 \\
\hline V. autolensis & 4.42 & 10.00 & 7.25 & 1.07 & 0.61 & 0.15 & 5.70 & 0.19 & 0.64 & 0.88 & 57.0 & 0.10 \\
\hline m1 sup. ant. & Surf & w & $\mathrm{b}$ & $\mathrm{h}$ & $\mathrm{S} / \mathrm{b}$ & $\mathrm{h} / \mathrm{b}$ & $r$ & $h / r$ & $\mathrm{~b} / 2 \mathrm{r}$ & $w / 2 r$ & skewness & mean dev \\
\hline V. rambliensis & 3.12 & 10.00 & 7.75 & 0.71 & 0.40 & 0.09 & 5.24 & 0.14 & 0.74 & 0.95 & 58.3 & 0.19 \\
\hline V. cristinae mean & 2.85 & 10.00 & 6.06 & 0.85 & 0.47 & 0.14 & 3.91 & 0.22 & 0.78 & 1.29 & 52.17 & 0.10 \\
\hline V. autolensis & 4.44 & 10.00 & 7.42 & 1.04 & 0.60 & 0.14 & 7.09 & 0.15 & 0.52 & 0.71 & 61.7 & 0.07 \\
\hline V. duplex & 4.30 & 10.00 & 7.60 & 0.95 & 0.57 & 0.13 & 7.80 & 0.12 & 0.49 & 0.64 & 47.7 & 0.04 \\
\hline m1 sup. post. & Surf & $w$ & $\mathrm{~b}$ & $\mathrm{~h}$ & $\mathrm{~S} / \mathrm{b}$ & $\mathrm{h} / \mathrm{b}$ & $r$ & $h / r$ & $b / 2 r$ & $w / 2 r$ & skewness & mean dev \\
\hline V. rambliensis & 3.77 & 10.00 & 8.21 & 0.78 & 0.46 & 0.10 & 5.66 & 0.14 & 0.72 & 0.88 & 65.3 & 0.24 \\
\hline V. cristinae mean & 3.64 & 10.00 & 7.14 & 0.91 & 0.51 & 0.13 & 4.57 & 0.20 & 0.79 & 1.10 & 55.43 & 0.16 \\
\hline V. autolensis & 4.18 & 10.00 & 7.48 & 1.07 & 0.56 & 0.14 & 6.05 & 0.18 & 0.62 & 0.83 & 53.7 & 0.09 \\
\hline V. duplex & 3.75 & 10.00 & 7.55 & 0.91 & 0.50 & 0.12 & 7.93 & 0.11 & 0.48 & 0.63 & 53.7 & 0.07 \\
\hline m2 sup. ant. & Surf & w & $\mathrm{b}$ & $\mathrm{h}$ & $\mathrm{S} / \mathrm{b}$ & $\mathrm{h} / \mathrm{b}$ & $r$ & $\mathrm{~h} / \mathrm{r}$ & $\mathrm{b} / 2 \mathrm{r}$ & $w / 2 r$ & skewness & mean dev \\
\hline V. rambliensis mean & 2.32 & 10.00 & 6.50 & 0.63 & 0.35 & 0.10 & 4.28 & 0.15 & 0.77 & 1.20 & 55.23 & 0.17 \\
\hline V. cristinae mean & 4.37 & 10.00 & 6.80 & 1.14 & 0.65 & 0.17 & 3.84 & 0.30 & 0.89 & 1.30 & 62.55 & 0.12 \\
\hline V. autolensis & 4.97 & 10.00 & 6.54 & 1.21 & 0.76 & 0.19 & 4.71 & 0.26 & 0.69 & 1.06 & 48.6 & 0.04 \\
\hline V. duplex & 5.86 & 10.00 & 7.61 & 1.31 & 0.77 & 0.17 & 5.74 & 0.23 & 0.66 & 0.87 & 56.6 & 0.07 \\
\hline m2 sup. post. & Surf & w & $\mathrm{b}$ & $\mathrm{h}$ & $\mathrm{S} / \mathrm{b}$ & $\mathrm{h} / \mathrm{b}$ & $r$ & $\mathrm{~h} / \mathrm{r}$ & $\mathrm{b} / 2 \mathrm{r}$ & $w / 2 r$ & skewness & mean dev \\
\hline V. rambliensis mean & 2.95 & 10.01 & 7.31 & 0.68 & 0.40 & 0.09 & 4.98 & 0.14 & 0.73 & 1.01 & 54.02 & 3.16 \\
\hline V. cristinae mean & 3.39 & 10.00 & 7.61 & 0.83 & 0.45 & 0.11 & 5.32 & 0.16 & 0.72 & 0.95 & 59.90 & 0.18 \\
\hline V. autolensis & 4.01 & 10.00 & 7.84 & 0.95 & 0.51 & 0.12 & 8.08 & 0.12 & 0.49 & 0.62 & 56.7 & 0.11 \\
\hline V. duplex & 4.77 & 10.00 & 8.13 & 1.05 & 0.59 & 0.13 & 7.76 & 0.14 & 0.52 & 0.64 & 56.9 & 0.08 \\
\hline
\end{tabular}

otropid connected to the posterolophid, as in $V$. cristinae and $V$. aff. multicrestatus.

Upper molars. The upper molars of $V$. autolensis, $V$. rugosus, $V$. duplex and $V$. pannonicus generally have between nine and 11 ridges, whereas $V$. priscus, $V$. bacchius, $V$. elegans, $V$. aff. multicrestatus and $V$. cristinae have a smaller number of ridges (8-9). The number of extra ridges in the upper molars of $V$. rambliensis sp. nov. is not con- stant in all elements. While the prototrope is constant in M1-2-3, only one out of six M2 have an extra ridge between the centrolophs and one metatrope. Outside the trigone only one out of two M1 has a short anterotrope.

The Vasseuromys species, except $V$. priscus and $V$. bacchius, have short, medium or long anterotrope and/or posterotrope in the upper dentition. The strong reduction in number and degree of 
TABLE 3. Comparison of $h / r$ concavity values. The limits between weakly and moderately concave are taken from Freudenthal and Martín-Suárez (2007b).

\begin{tabular}{|l|c|c|c|c|c|c|c|c|}
\hline \multicolumn{1}{|c|}{ h/r } & \multicolumn{2}{c|}{$\mathbf{m 1}$} & \multicolumn{2}{c|}{$\mathbf{m 2}$} & \multicolumn{3}{c|}{ M1 } & \multicolumn{2}{c|}{ M2 } \\
\hline \multicolumn{1}{|c|}{ species } & ant & post & ant & post & ant & post & ant & post \\
\hline V. rambliensis & 0.09 & 0.08 & 0.14 & 0.09 & 0.14 & 0.14 & 0.15 & 0.14 \\
\hline V. cristinae & 0.07 & 0.18 & 0.14 & 0.15 & 0.22 & 0.20 & 0.30 & 0.16 \\
\hline V. autolensis & & & 0.10 & 0.19 & 0.15 & 0.18 & 0.26 & 0.12 \\
\hline V. duplex & 0.05 & 0.08 & & & 0.12 & 0.11 & 0.23 & 0.14 \\
\hline limit weak/moderate & 0.18 & 0.13 & 0.17 & 0.13 & 0.15 & 0.12 & 0.14 & 0.11 \\
\hline
\end{tabular}

development of the extra ridges in the upper molars of $V$. rambliensis sp. nov. is only comparable to that described for $V$. bacchius, which shows no extra ridges outside the trigone.

Another difference between $V$. rambliensis sp. nov. and the rest of the Vasseuromys species is the kind of connection of the metaloph, which is usually transverse and connected to the protocone. As a consequence of this kind of connection a transverse valley, open or closed to the lingual border of the teeth, occurs between the posteroloph and the metaloph. Although this morphotype is constant in all previously known Vasseuromys assemblages, it is absent in $\mathrm{V}$. rambliensis sp. nov. All upper elements, except the D4, have a metaloph not connected to the protocone. The lingual end of the metaloph is connected to the posteroloph, thus closing the posterior valley. This morphotype allows the distinction of the upper molars of $V$. rambliensis sp. nov. from those of the other species of the genus.

\section{Biostratigraphy}

The published Vasseuromys species cover the range between zone MN1 and MN11 (Daams, 1999). The time span between MN1 and the upper part of MN2 in Europe and Turkey has a well-documented record of Vasseuromys (de Bonis, 1973; Cuenca, 1985; Martínez-Salanova, 1987; ÁlvarezSierra, et al. 1991; Ünay, 1994; Ünay and Göktas, 2000). The species in MN1 are V. autolensis, $V$. priscus and $V$. rugosus in Europe and $V$. aff. duplex in Turkey. In Europe, in the lower part of zone MN2, only $V$. rugosus is present, whereas in the upper part of zone MN2 $V$. rugosus and $V$. bacchius occur. In MN2 of Anatolia the characteristic species is $V$. duplex.

In zone MN3, until now, only $V$. elegans had been recorded (Stubersheim 3, Wu, 1993). Only five European localities (Erkertshofen 2, Petersbuch 2, Blanquatère 1, SC 109 and Pico del Fraile 2) have yielded remains of Vasseuromys in the time span between MN4/MN5. In Erkertshofen 2 and Petersbuch 2 (MN4), Wu (1993) recognized V. aff. elegans. Aguilar and Lazzari (2006) described $V$. aff. elegans together with $V$. aff. priscus and Vasseuromys sp. from Blanquatère 1, but in view of the excessive number of species (34 rodent species) the homogeneity of this locality is questionable.

Only $V$. aff. multicrestatus is known in MN5/ MN9 (Agustí et al., 2011) and V. pannonicus is documented in the Late Vallesian and Early Turolian deposits of Europe (MN10/MN11) (Daxner Höck and de Bruijn, 1981; de Bruijn, 1989; Daams, 1999; Daxner-Höck and Höck, 2009).

The absence in PF1 of the genera Eucricetodon and Democricetodon, the predominance of Ligerimys and the presence of $P$. murinus are biostratigraphically significant and allow attribution of this locality to zone A (MN3) of the Ramblian.

The presence of $V$. rambliensis $\mathrm{sp}$. nov. in PF1 implies the coexistence in unit MN3 of more than one species of Vasseuromys, as also happens in MN1 with $V$. autolensis, $V$. priscus and $V$. rugosus and in the upper part of MN2 with $V$. rugosus and V. bacchius (Daams, 1999).

\section{Origin and Phylogeny of Vasseuromys}

The oldest records of Vasseuromys are from the Late Oligocene of Bergasa (Lacomba, 1988) and Ventas 4 (Cuenca et al., 1992). Bergasa (Ebro basin, Spain) contains an unpublished fossil assemblage including a new species of Ebromys, according to Lacomba (1988), based on the strong concavity of the occlusal surface, the absence of an endoloph in $\mathrm{M} 1-2$, and the anterior prolongation of the labial tubercles in m1-2. Ebromys (=Vasseuromys) bergasensis from Bergasa is clearly the smallest species of the genus. The development of extra ridges in lower and upper molars is less than in the rest of the species. The lengths and connections of the centrolophids are very similar to those in the other species, except for $V$. bacchius and $V$. rambliensis sp. nov. from PF1, where this ridge is clearly shorter.

These features make us consider that the Vasseuromys ancestor was a small-sized species 


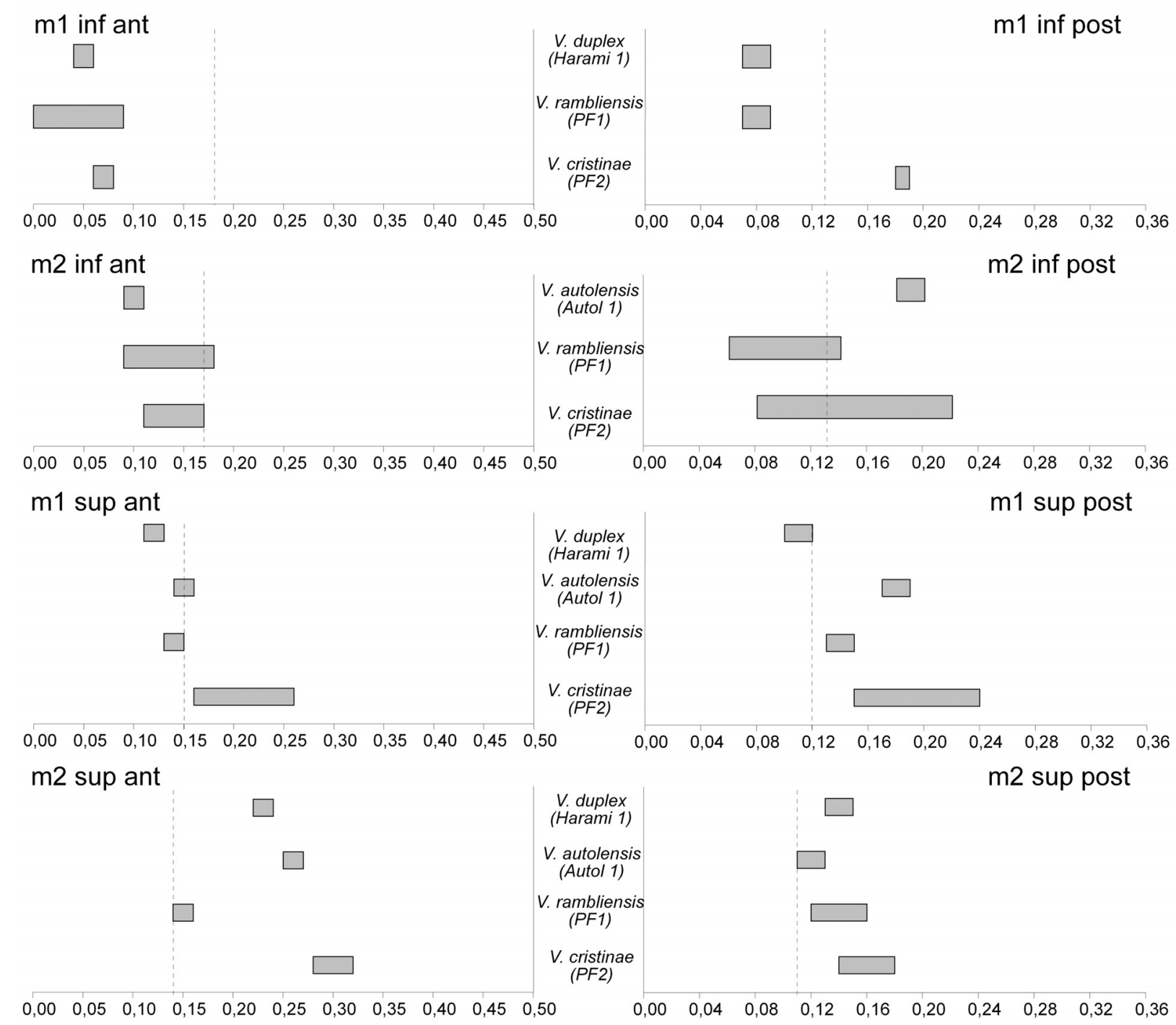

FIGURE 7. Ranges of concavity of anterior and posterior side of $\mathrm{m} 1, \mathrm{~m} 2, \mathrm{M} 1$ and $\mathrm{M} 2$ of Vasseuromys duplex from Harami 1, V. autolensis from Autol 1, V. rambliensis sp. nov. from PF1 and V. cristinae from PF2. The dashed lines indicate the limits between weakly and moderately concave (from Freudenthal and Martín-Suárez, 2007b).

with a less complicated dental pattern than most of the Miocene species of the genus.

Some Late Oligocene glirids present metric and morphological resemblances with the oldest form of Vasseuromys. The most probable ancestor of Vasseuromys is Peridyromys columbarii from Sayatón 6 (Madrid basin, Spain) (Daams, 1989). The long centrolophids, frequently reaching the labial tooth border of the m1-2, the complex dental pattern of the upper molars and the size, are very similar in both forms. On the contrary, the presence of an extra ridge in the anterior valley of the lower molars in Bergasa, led Daams (1989) to distinguish them. Nevertheless, the exclusive morphotype without anterotropid of $P$. columbarii is also present in the lower molars of the Vasseuromys assemblage from Bergasa ( $40 \%$ in $\mathrm{m} 2$ and $47 \%$ in $\mathrm{m} 3$ ).

In view of these data, a phylogenetic relationship may exist between Peridyromys and Vasseuromys. According to Daams (1999), Peridyromys is the oldest genus of the Myomiminae and, probably, the ancestor of a number of other genera such as Armantomys, Altomiramys, Praearmantomys, Pseudodryomys, etc. According to Daams (1999), the teeth of Peridyromys are relatively small, and its first representatives have a moderately complex dental pattern ( $P$. murinus from St. Victor-la-Coste and Coderet, Upper Oligocene-MP30, France and $P$. columbarii from Sayatón 6, Upper OligoceneMP30). 
Vasseuromys rambliensis sp. nov. is found in the Ramblian deposits of local zone A (Larrasoaña et al., 2006). Therefore, its ancestor must be sought in some of the Vasseuromys species from MN1 or MN2.

Two sets of localities may contain this ancestor, one situated in the East (Anatolia-Turkey) and the other one in the West (Europe) of the Mediterranean.

Ünay (1994) considered that the two forms of the genus Vasseuromys of the Turkish assemblages ( $V$. duplex from Harami 1, 2 and 3, and $V$. aff. duplex from Kilçak 0, 0", 3A and 3B) constitute a lineage restricted to the eastern Mediterranean. In this lineage there are two anterotropids and one posterotropid, and in the Turkish material the centrolophids are never as long as they are in V. rugosus from European localities. While in the Turkish species two anterotropids are present, in V. rambliensis sp. nov. this ridge is less developed, especially in $\mathrm{m} 1$. The length of the centrolophids of $V$. rambliensis $\mathrm{sp}$. nov. and the ridge pattern of the posterior valley are more similar to those of Turkish material than those of $V$. rugosus from MN2. In spite of these similarities and on the basis of the development of the anterotropids, we reject the possibility that $V$. rambliensis sp. nov. is a descendant of the Turkish lineage.

Four species (V. priscus, V. rugosus, V. autolensis and $V$. bacchius) from European localities of MN1-MN2 are potential ancestors of $V$. rambliensis $\mathrm{sp}$. nov. The dental pattern of $V$. rambliensis $\mathrm{sp}$. nov. from PF1 is simpler than that of most of these species, but $V$. priscus has an even simpler dental pattern. $V$. priscus is characterized by one extra ridge in the upper molars and two in the lower ones. $V$. rambliensis $\mathrm{sp}$. nov. has generally three extra ridges in the upper molars and four in the lower molars; this difference seems to be sufficient to reject $V$. priscus as ancestor of $V$. rambliensis sp. nov.

The dental pattern of $V$. rugosus is more complex than that of $V$. rambliensis sp. nov. The main differences between both taxa lie in the number of extra ridges in the lower molars, especially in the posterior valley, in the development of the centrolophid and in the number of extra ridges inside the trigone. In $V$. rugosus three posterotropids are present in all $\mathrm{m} 1-2$ and two or three in the $\mathrm{m} 3$; in $V$. rambliensis $\mathrm{sp}$. nov. only one single posterotropid is present in all lower molars. In V. rugosus the centrolophids are long and reach the labial border, in $V$. rambliensis sp. nov. the centrolophids usually do not reach the middle of the tooth. In $V$. rugosus the trigone has three well-developed extra ridges (Álvarez-Sierra et al., 1991), in V. rambliensis sp. nov. the development of these ridges is less, with a tendency of the central one (between centrolophs) and the posterior one (metatrope) to be absent. Therefore, it is improbable that $V$. rugosus is the ancestor of $V$. rambliensis sp. nov.

Álvarez-Sierra et al. (1991) consider V. bacchius as an off-shoot of $V$. autolensis. The locality Fuenmayor 2 is younger than those that contain $V$. autolensis (Autol, Quel 1). The locality PF1, in turn, is younger than Fuenmayor 2, and there may well be an evolution in situ $V$. autolensis - $V$. bacchius $V$. rambliensis sp. nov.

In $V$. bacchius the teeth are larger, the dental pattern is slightly simpler, the centrolophids are somewhat shorter than in Autol, and the labial cusps of the lower molars are not longitudinally elongated.

From $V$. bacchius to $V$. rambliensis sp. nov. a further simplification of the dental pattern takes place (reduction of length in the extra ridges of the lower molars, reduction of number and development of extra ridges in the trigone of the upper molars). Contrary to the trend from $V$. autolensis to $V$. bacchius, V. rambliensis sp. nov. is on average smaller than $V$. bacchius.

\section{CONCLUSIONS}

Vasseuromys rambliensis sp. nov. from PF1 represents the first record of this genus in the MN3 zone of the Iberian Peninsula. Its presence implies the existence in the MN3 zone of two species of Vasseuromys with different dental patterns.

The size of this new glirid species is intermediate between the large $V$. bacchius and the rest of species of the genus.

The new species is characterized by the constant presence of four extra ridges, metalophid always connected to the metaconid and mesolophid connected to the entoconid in the lower molars. The anterotropid shows a strong reduction in $\mathrm{m} 1$, is less reduced in $\mathrm{m} 2$ and is of medium length in $\mathrm{m} 3$. The development of the centrolophid is very similar to the $V$. bacchius and reduced with respect to the rest of the species.

In the upper molars the most striking feature is the kind of connections of the lingual side of the metaloph. While in the rest of the Vasseuromys species the metaloph is connected to the protocone, in $V$. rambliensis sp. nov. the lingual part of the metaloph is directed backward, connecting with the posteroloph. 
In the Iberian lineage $V$. autolensis (MN1) - $V$. bacchius (upper part of MN2) - V. rambliensis sp. nov. (MN3) there is a progressive simplification of the dental pattern.

\section{ACKNOWLEDGMENTS}

We are grateful to A. Urmeneta and R. Arcos (Comunidad de las Bardenas Reales de Navarra), E. Martínez and S. García (Aula Paleontológica de Cenicero) for their help during sampling. We thank P. Gómez and E. Navarro (SCSIE, UV) for capable laboratory assistance. This research was supported by projects BTE2003-7252, CGL2004-0780, CGL2007/66431/C02-02 and GVPRE/2008/320.

\section{REFERENCES}

Aguilar, J.P. and Lazzari, V. 2006. Nouvelles espèces de gliridés du gisement karstique de Blanquatère 1 (Miocène moyen, sud de la France). Geodiversitas, 28-2:277-295.

Agustí, J., Pérez-Rivarés, F.J., Cabrera, L., Garcés, M., Pardo, G., and Arenas, C. 2011. The Ramblian-Aragonian boundary and its significance for the European Neogene continental chronology. Contributions from the Ebro Basin record (NE Spain). Geobios, 44(2-3):121-134.

Alonso-Zarza, A.M., Armenteros, A., Braga, J.C., Muñoz, A., Pujalte, V., Ramos, E., Aguirre, J., Alonso-Gavilán, G., Arenas, C., Baceta, J.I., Carballeira, J., Calvo, J.P., Corrochano, A., Fornós, J.J., González, A., Luzón, A., Martín, J.M., Pardo, G., Payros, A., Pérez, A., Pomar, L., Rodríguez, J.M., and Villena, J. 2002. Tertiary, p. 293-334. In Gibbons, W. and Moreno, T. (eds.), The Geology of Spain. Geological Society, London.

Álvarez-Sierra, M.A., Daams, R., Lacomba, J.I., López Martínez, N., Van der Meulen, A.J., Sesé, C., and de Visser, J. 1991. Palaeontology and biostratigraphy (micromammals) of the continental Oligocene-Miocene deposits of the North-Central Ebro Basin (Huesca, Spain). Scripta Geologica, 94:1-77.

Arenas, C. and Pardo, G. 1999. Latest Oligocene-late Miocene lacustrine systems of the north-central part of the Ebro Basin (Spain): sedimentary facies model and paleogeographic synthesis. Palaeogeography, Palaeoclimatology, Palaeoecology, 151:127-148.

Armour-Brown, A., de Bruijn, H., Maniati, C., Siatos, G., and Niesen, P. 1977. The Geology of the Neogene sediments north of Serrai and the use of rodent faunas for biostratigraphic control.; Athens 1977, Proceedings VI Colloquium on the Geology of the Aegean Region, 2:615-622.

Baudelot, S. and de Bonis, L. 1966. Nouveaux Gliridés (Rodentia) de l'Aquitanien du basin d'Aquitaine. Comptes Rendus Sommaires Societé Geologique de la France, 9:342-343.
Bowdich, T.E. 1821. An Analysis of the Natural Classifications of Mammalia for the Use of Students and Travellers. J. Smith, Paris.

Cuenca, G. 1985. Los roedores (Mammalia) del Mioceno inferior de Autol (La Rioja). Ediciones Instituto de Estudios Riojanos-Ciencias de la Tierra, Logroño, Spain.

Cuenca, G., Canudo, J.I., Laplana, C., and Andrés, J.A. 1992. Bio y cronoestratigrafía con mamíferos en la Cuenca Terciaria del Ebro: ensayo de síntesis. Acta Geológica Hispánica, 27(1-2):127-143.

Daams, R. 1989. The micromammal fauna from the Upper Oligocene of Sayatón 6, Madrid Basin, prov. of Guadalajara, Spain. Scripta Geologica, 89:57-69.

Daams, R. 1999. Family Gliridae, p. 301-318. In Rössner, G.E. and Heissig, K. (eds.), Land Mammals of Europe. Verlag Dr. Friedrich Pfeil, München.

Daams, R., van der Meulen, A.J., Álvarez-Sierra, M.A., Peláez-Campomanes, P., Calvo, J.P., Alonso-Zarza, M.A., and Krijgsman, W. 1999. Stratigraphy and sedimentology of the Aragonian (Early to Middle Miocene) in its type area (North-Central Spain). Newsletters on Stratigraphy, 37:103-139.

Daxner-Höck, G. and de Bruijn, H. 1981. Gliridae (Rodentia, Mammalia) des Eichkogels bei Mödling (Niederösterreich). Paläeontologische Zeitschrift, 552:157-172.

Daxner-Höck, G. and Höck, E. 2009. New data on Eomyidae and Gliridae (Rodentia, Mammalia) from the Late Miocene of Austria. Annalen des Naturhistorischen Museums in Wien, 111-A:375-444.

de Bonis, L. 1973. Contribution a l'étude des mammifères de l'Aquitanien de l'Agenais. Rongeurs, Carnivores-Perisodactyles. Mémoires du Muséum d'Histoire Naturelle, 28:1-192.

de Bruijn, H. 1989. Smaller mammals from the Upper Miocene and Lower Pliocene of the Strimon Basin, Greece: Part 1. Rodentia and Lagomorpha. Bollettino della Società Paleontologica Italiana, 28:189-195.

Engesser, B. 1976. Zum Milchgebiss der Dimyliden (Insectivora, Mammalia). Eclogae Geologicae Helvetiae, 69(3):795-808

Freudenthal, M. 2004. Gliridae (Rodentia, Mammalia) from the Eocene and Oligocene of the Sierra Palomera (Teruel, Spain). Treballs del Museu de Geologia de Barcelona, 12:97-173.

Freudenthal, M. and Martín-Suárez, E. 2007a. Revision of the subfamily Bransatoglirinae (Gliridae, Rodentia, Mammalia). Scripta Geologica, 135:241-273.

Freudenthal, M. and Martín-Suárez, E. 2007b. An index for concavity of the occlusal surface of the cheek teeth and an assessment of concavity in Gliridae (Mammalia, Rodentia). Palaeontologia Electronica, 10-2:1-24.

$9 \mathrm{~A}: 24 \mathrm{p}, 1.3 \mathrm{MB}$

http://palaeo-electronica.org/2007_2/00122/index.html

Hugueney, M. and Adrover, R. 19900. Rongeurs (Rodentia, Mammalia) de l'Oligocène de Sineu (Baleares, Espagne). Paleontologia i Evolució, 23:157-169. 
Kretzoi, M. 1978. Wichtigere Streufunde in der Wirbeltierpalaontologischen Sammlung der Ungarischen Geologischen Anstalt. Magyar Állami Földtani Intézet Évi Jelentése, 1:348-358.

Lacomba, J.I. 1988. Estudio de las faunas de micromamíferos del Oligoceno superior y Mioceno inferior en las cuencas de Loranca, Ebro riojano y Ebro aragonés. Aspectos paleoecológicos. Unpublished PhD Thesis, Universidad Complutense de Madrid, Madrid, Spain.

Larrasoaña, J.C., Murelaga, X., and Garcés, M. 2006. Magnetobiochronology of Lower Miocene (Ramblian) continental sediments from the Tudela Formation (western Ebro basin, Spain). Earth and Planetary Science Letters, 243:409-423.

Lourens, L.J., Hilgen, F.J., Shackleton, N.J., Laskar, J., and Wilson, D.S. 2004. The Neogene period, p. 409440. In Gradstein, F.N., Ogg, J.G., and Smith, A.G. (eds.), A Geologic Time Scale 2004. Cambridge University Press, Cambridge

Martínez-Salanova, J. 1987. Estudio paleontológico de los micromamíferos del Mioceno inferior de Fuenmayor (La Rioja). Ediciones Instituto de Estudios Riojanos-Ciencias de la Tierra, Logroño, Spain.

Muirhead, L. 1819. Mazology, p. 1-744. In Brewster, D. (ed.), The Edinburgh Encyclopaedia. Fourth ed. William Blackwood, Edinburgh.

Murelaga, X. 2000. Estudio de las faunas de vertebrados del Mioceno inferior de las Bardenas Reales de Navarra y áreas colindantes (Cuenca del Ebro, Navarra). Unpublished PhD Thesis, Universidad del País Vasco, Bilbao.

Murelaga, X., Larrasoaña, J.C. and Garcés, M. 2004b. Nueva localidad fosilífera en el Mioceno inferior de las Bardenas Reales de Navarra (Cuenca del Ebro, Península Ibérica). Geogaceta, 36:179-182.

Murelaga, X., Astibia, H., Sesé, C., Soria, D., and Pereda-Suberbiola, X. 2004a. Mamíferos del Mioceno inferior de las Bardenas Reales de Navarra (Cuenca del Ebro, Península Ibérica). Munibe, 55:7102.
Ruiz-Sánchez, F.J., Murelaga, X., Freudenthal, M., Larrasoaña, J.C., and Garcés, M. 2010a. Presencia del género Vasseuromys (Gliridae, Rodentia) en la sección de Pico del Fraile (Bardenas Reales de Navarra, Cuenca del Ebro, España). Publicaciones del Seminario de Paleontología de Zaragoza, 9: 277-280.

Ruiz-Sánchez, F.J., Murelaga, X., Freudenthal, M., Larrasoaña, J.C., and Garcés, M. (in press) a. Hypsodont Myomiminae (Gliridae, Rodentia) from the Lower Miocene Tudela Formation (Bardenas Reales, Ebro Basin, Spain) and their bearing on the age of the Agenian-Ramblian boundary. Geodiversitas.

Ruiz-Sánchez, F.J., Murelaga, X., Freudenthal, M., Larrasoaña, J.C., and Garcés, M. (in press) b. A new Vasseuromys species from the Aragonian of Ebro basin (Spain). Acta Palaeontologica Polonica.

Ruiz-Sánchez, F.J., Murelaga, X., Freudenthal, M., Larrasoaña, J.C., Garcés, M., Crespo-Roures, V.D., Mansino-Paris, S., and González-Pardos, M. 2010b. Pico del Fraile 2 (PF2), una nueva localidad de edad Aragoniense en la Cuenca del Ebro (Bardenas Reales de Navarra). Publicaciones del Seminario de Paleontología de Zaragoza, 9: 281-284.

Ünay, E. 1994. Early Miocene rodent faunas from the eastern Mediterranean area. Part IV. The Gliridae. Proceedings Koninklijke Nederlandse Akademie van Wetenschappen, 97-4:445-490.

Ünay, E. and Göktaş, F. 2000. Kinik (Gördes) Çevresindeki Erken Miyosen Yaşli Linyitli Çökellerin Küçük Memeli Biyokronolojisi: Ön Sonuçlar. Türkiye Jeoloji Bülteni, 43:1-5.

Van der Meulen, A.J. and Daams, R. 1992. Evolution of Early-Middle Miocene rodent faunas in relation to long-term palaeoenvironmental changes. Palaeogeography, Palaeoclimatology, Palaeoecology, 93:227-253.

Wu, W. 1993. Neue Gliridae (Rodentia, Mammalia) aus untermiozänen (orleanischen) Spaltenfüllungen Süddeutschlands. Documenta Naturae, 81:1-149. 